\title{
Extended and refined multi sensor reanalysis of total ozone for the period 1970-2012
}

\author{
R. J. van der A, M. A. F. Allaart, and H. J. Eskes \\ KNMI, P.O. Box 201, 3730 AE De Bilt, the Netherlands \\ Correspondence to: R. J. van der A (avander@knmi.nl)
}

Received: 23 January 2015 - Published in Atmos. Meas. Tech. Discuss.: 24 March 2015

Revised: 13 July 2015 - Accepted: 14 July 2015 - Published: 30 July 2015

\begin{abstract}
The ozone multi-sensor reanalysis (MSR) is a multi-decadal ozone column data record constructed using all available ozone column satellite data sets, surface Brewer and Dobson observations and a data assimilation technique with detailed error modelling. The result is a high-resolution time series of 6-hourly global ozone column fields and forecast error fields that may be used for ozone trend analyses as well as detailed case studies.

The ozone MSR is produced in two steps. First, the latest reprocessed versions of all available ozone column satellite data sets are collected and then are corrected for biases as a function of solar zenith angle (SZA), viewing zenith angle (VZA), time (trend), and stratospheric temperature using surface observations of the ozone column from Brewer and Dobson spectrophotometers from the World Ozone and Ultraviolet Radiation Data Centre (WOUDC). Subsequently the de-biased satellite observations are assimilated within the ozone chemistry and data assimilation model TMDAM.

The MSR2 (MSR version 2) reanalysis upgrade described in this paper consists of an ozone record for the 43-year period 1970-2012. The chemistry transport model and data assimilation system have been adapted to improve the resolution, error modelling and processing speed. Backscatter ultraviolet (BUV) satellite observations have been included for the period 1970-1977. The total record is extended by 13 years compared to the first version of the ozone multi sensor reanalysis, the MSR1. The latest total ozone retrievals of 15 satellite instruments are used: BUV-Nimbus4, TOMSNimbus7, TOMS-EP, SBUV-7, -9, -11, -14, -16, -17, -18, -19, GOME, SCIAMACHY, OMI and GOME-2. The resolution of the model runs, assimilation and output is increased from $2^{\circ} \times 3^{\circ}$ to $1^{\circ} \times 1^{\circ}$. The analysis is driven by 3-hourly meteorology from the ERA-Interim reanalysis of
\end{abstract}

the European Centre for Medium-Range Weather Forecasts (ECMWF) starting from 1979, and ERA-40 before that date. The chemistry parameterization has been updated. The performance of the MSR2 analysis is studied with the help of observation-minus-forecast $(\mathrm{OmF})$ departures from the data assimilation, by comparisons with the individual station observations and with ozone sondes. The OmF statistics show that the mean bias of the MSR2 analyses is less than $1 \%$ with respect to de-biased satellite observations after 1979.

\section{Introduction}

Since the 1950s, total ozone columns have been observed with a network of Dobson spectrophotometers (e.g. Brönnimann et al., 2003). Later, the network became part of the Global Atmospheric Watch (GAW) program of WMO. From the early 1980s Brewer instruments were added to this network. The performance of this network is discussed by Fioletov et al. (2008). Regular monitoring of the ozone layer with satellites started in 1970 with the backscatter ultraviolet (BUV) instrument on Nimbus-4 (Krueger et al., 1980) and continued from 1978 with SBUV and TOMS instruments on the satellite Nimbus-7. After the discovery of the Antarctic ozone hole in 1985 (Farman et al., 1985), ozone layer monitoring was intensified and new satellite missions were planned. Since then, trend studies of ozone based on satellite observations have been published by many authors (e.g. Stolarski et al., 1991; Fioletov et al., 2002; Weber et al., 2014; WMO 2014). For the reconstruction of stratospheric ozone, data assimilation has become an important tool. An example is the European Centre for Medium-Range Weather Forecasts (ECMWF) ERA-40 reanalysis of total ozone (De- 
thof and Hólm, 2004). More recently, an atmospheric composition time series covering the 10-year period from 2003 to 2012 became available as part of the Seventh Framework Programme-funded Monitoring Atmospheric Composition and Climate (MACC) project (Inness et al., 2013), based on the assimilation of satellite measurements.

Multi-decadal structural homogeneous data sets of observed ozone are important for Montreal Protocol monitoring (WMO, 2014), climate studies (IPCC report, 2013; Weber et al., 2014), trend analyses (e.g. Stolarski et al., 1991, 2006; Fioletov et al, 2002; Brunner et al., 2006; WMO, 2007; Mäder et al, 2007; Harris et al., 2008; Chehade et al., 2014; Coldewey-Egbers et al., 2014) and UV radiation calculations at the Earth's surface (Lindfors et al., 2009; Krzyścin, 2008). Such an ozone data set is also important for quantifying ozone depletion and detecting the first signs of recovery (e.g. Reinsel et al., 2005) as a result of the actions to reduce ozone-depleting substances as regulated by the Montreal Protocol and its amendments and adjustments. Signs of recovery of the ozone layer have been reported in the latest WMO/UNEP scientific assessment of ozone depletion (WMO, 2014). Such applications of accurate long time series of ozone have motivated the development of the ozone multisensor reanalysis (MSR1, van der A et al., 2010) for the time period 1978-2008. Recent applications of the MSR1 are for researching ozone trends (e.g. Antón et al., 2011; Kuttippurath et al., 2013; Knibbe et al, 2014), climate (e.g. van Noije et al., 2014) and UV (e.g. den Outer, 2012) and are used in the latest WMO/UNEP scientific assessment (WMO, 2014). De Laat et al. (2015) have used the MSR1 in a multivariate regression to study the recovery of the Antarctic ozone hole. The MSR1 has also been used to provide stratospheric ozone boundary conditions to tropospheric chemistry transport models (e.g. Huijnen et al., 2010). Apart from long-term climate records, the multi-sensor reanalysis offers detailed synoptic ozone maps, available every $6 \mathrm{~h}$ with detailed error estimates. This rich source of information can be used to study local time series and events, such as the unique September 2002 warming event that split the Antarctic vortex into two sub-vortices (Eskes et al., 2005).

Five years have passed since the MSR1 became available, and new reprocessed satellite data have become available. Therefore we have extended our Multi Sensor Reanalysis (van der A et al., 2010) based on satellite observations to a period covering 43 years. The new ozone Multi Sensor Reanalysis version 2 (MSR2), described in this paper, covers the period 1970-2012 by including BUV observations for the first 8 years and recent observations for the years from 2009 to 2012. Total ozone data sets from the satellite instruments BUV (on the satellite Nimbus-4), TOMS (Nimbus7 and Earth Probe), SBUV (Nimbus-7, NOAA- 9, 11, 14, 16, 17, 18, and 19), GOME (ERS-2), SCIAMACHY (Envisat), OMI (EOS-Aura), and GOME-2 (Metop-A) have been used in MSR2. Most retrieval algorithms of those ozone data sets have recently been improved and the data upgraded to a newer data release.

In the new MSR2, several improvements have been made to the methodology. In particular, the spatial resolution of the model runs, assimilation and output is increased from $2^{\circ} \times 3^{\circ}$ to $1^{\circ} \times 1^{\circ}$. The chemistry parameterization of the model has been updated and the model is driven by 3-hourly meteorology. Furthermore, new corrections for the satellite data have been derived.

As explained in detail in van der A et al. (2010) the MSR is constructed in two steps. In the first step all available satellite data are collected and corrected by a multiple regression fit with selected ground-based observations of ozone. Parameters in this fit are time, the solar zenith angle (SZA), the viewing zenith angle (VZA) and the effective ozone temperature. In the second step the corrected satellite data are assimilated into a global chemistry transport model. The assimilated ozone fields are the resulting multi sensor reanalysis of ozone.

In the next sections we will describe the current methodology of correcting the satellite observations, the improvements made to the data assimilation, and an evaluation and discussion of the results.

\section{Correcting the total ozone observations}

\subsection{Satellite-based total ozone measurements}

Figure 1 shows the timelines of all satellite instruments used to generate the MSR2 reanalysis, which reveals gaps and overlaps between these records. To extend the data set into the 1970s, the observations from the BUV instrument on Nimbus-4 (Krueger et al., 1980; Stolarski et al., 1997) have been added. They are reprocessed with the new version 8.6 algorithm (Bhartia et al., 2013). Since 1978, significantly more ozone observations have become available with the TOMS and SBUV instruments on the satellite Nimbus7 (Bhartia et al., 2002; Miller et al., 2002). These observations were continued with TOMS instruments on the satellites Meteor 3, ADEOS and Earth Probe until 2003, when the measurements started to be seriously affected by instrument degradation. This time series of TOMS was interrupted from May 1993 until July 1996. This gap was filled by continuous SBUV observations on various NOAA satellite missions. The gap was also partly filled beginning in July 1995 with GOME observations aboard ERS-2 (Burrows et al., 1999), the first European satellite measuring total ozone from the UV spectral range. Although global coverage was lost due to an instrumental problem in 2003, the GOME instrument measured until 2011 with reduced coverage. GOME was followed up by the European satellite instruments SCIAMACHY (Bovensmann et al., 1999) launched in 2002 on the Envisat platform of the European Space Agency (ESA), and OMI (Levelt et al., 2006), a Dutch-Finnish instrument on the EOS-AURA platform of National Aeronautics and Space 
Table 1. The satellite data sets used in this study. The columns show (1) the name of the data set, (2) the satellite instrument, (3) the satellite, (4 and 5) the time period, (6) the maximum distance allowed in an overpass, (7) the number of ground stations (GS) and (8) the total number of overpasses for this data set.

\begin{tabular}{llllllll}
\hline Name & Instrument & Satellite & From & To & Dist. & no. GS & Overpasses \\
\hline BUV & BUV & Nimbus-4 & 1 Apr 1970 & 6 May 1977 & $2.00^{\circ}$ & 66 & 4201 \\
TOMS-N7 & TOMS & Nimbus-7 & 31 Oct 1978 & 6 May 1993 & $0.75^{\circ}$ & 135 & 182138 \\
TOMS-EP & TOMS & Earth probe & 25 Jul 1996 & 31 Dec 2002 & $0.75^{\circ}$ & 155 & 141775 \\
SBUVN07 & SBUV & Nimbus-7 & 31 Oct 1978 & 21 Jun 1990 & $2.00^{\circ}$ & 110 & 25366 \\
SBUVN09 & SBUV/2 & NOAA-9 & 2 Feb 1985 & 19 Feb 1998 & $2.00^{\circ}$ & 156 & 39139 \\
SBUVN11 & SBUV/2 & NOAA-11 & 1 Dec 1988 & 27 Mar 2001 & $2.00^{\circ}$ & 171 & 39926 \\
SBUVN14 & SBUV/2 & NOAA-14 & 5 Feb 1995 & 28 Sep 2006 & $2.00^{\circ}$ & 167 & 52423 \\
SBUVN16 & SBUV/2 & NOAA-16 & 3 Oct 2000 & 31 Dec 2003 & $2.00^{\circ}$ & 173 & 58844 \\
SBUVN17 & SBUV/2 & NOAA-17 & 11 Jul 2002 & 31 Dec 2011 & $2.00^{\circ}$ & 168 & 50074 \\
SBUVN18 & SBUV/2 & NOAA-18 & 5 Jun 2005 & 31 Dec 2011 & $2.00^{\circ}$ & 148 & 35797 \\
SBUVN19 & SBUV/2 & NOAA-19 & 23 Feb 2009 & 31 Dec 2011 & $2.00^{\circ}$ & 127 & 14976 \\
GDP5 & GOME-1 & ERS-2 & 27 Jun 1995 & 3 Jul 2011 & $1.80^{\circ}$ & 156 & 144645 \\
TOGOMI2 & GOME-1 & ERS-2 & 27 Jun 1995 & 3 Jul 2011 & $200 \mathrm{~km}$ & 155 & 146150 \\
SGP5 & SCIAMACHY & Envisat & 2 Aug 2002 & 8 Apr 2012 & $100 \mathrm{~km}$ & 139 & 86144 \\
TOSOMI2 & SCIAMACHY & Envisat & 2 Aug 2002 & 8 Apr 2012 & $100 \mathrm{~km}$ & 139 & 87938 \\
OMDOAO3 & OMI & Aura & 1 Oct 2004 & 31 Dec 2012 & $100 \mathrm{~km}$ & 123 & 172031 \\
OMTO3 & OMI & Aura & 1 Oct 2004 & 31 Dec 2012 & $100 \mathrm{~km}$ & 125 & 169325 \\
GOME2A & GOME-2 & Metop-A & 4 Jan 2007 & 31 Dec 2012 & $50 \mathrm{~km}$ & 136 & 110320 \\
\hline
\end{tabular}

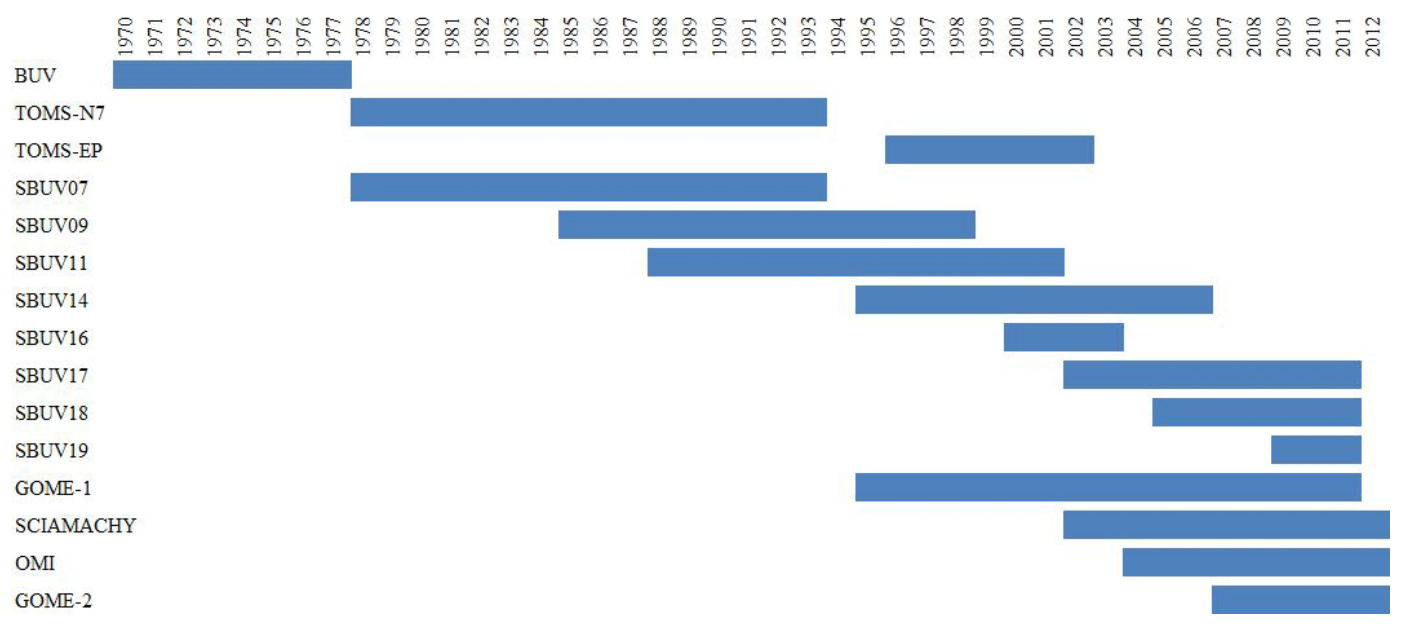

Figure 1. Data availability for each satellite instrument used in the ozone MSR2.

Administration (NASA), launched in 2004. The UV-VIS spectrometer GOME-2 (Callies et al., 2000) was launched in 2006 on the first of a series of three operational EUMETSAT Metop missions, which allows for the continuous monitoring of the ozone layer up until 2020. The complete collection of data sets used in MSR2 is listed in Table 1.

Almost all existing level 2 total ozone data sets from satellites have been used. Level 2 data are defined as the geolocated satellite retrieval results, while level 4 is defined as the assimilated satellite data provided as a gridded field. Data from the TOMS instruments on board the Meteor3 and ADEOS satellites and data from the FY-3 satellite were only available as gridded (level 3) data: unfortunately this is not suitable for data assimilation. Data from OMPS on the Suomi National Polar-orbiting Partnership (NPP) platform and from GOME-2 on METOP-B were not used because these time series are currently too short for deriving corrections.

In Fig. 2 we show how the number of annual satellite observations grew by several orders of magnitude throughout the years. In the 1970s, the number of observations was still sparse with several big gaps in time without data. The longest time period without data is from May 1977 until October 1978, which explains the dip in 1977 in Fig. 2. Another shorter period without observations exists from June to September 1976. The dip around 1994 corresponds to the end of a long period of TOMS observations on Nimbus 7, 2 years 
Table 2. Regression coefficients (expressed as corrections) for the various ozone data sets. The columns show (1) name; (2) RMS original data; (3) offset correction; (4) trend correction; (5) viewing zenith angle correction; (6) linear solar zenith angle correction; (7) second-order solar zenith angle correction; (8) effective ozone temperature correction. The last line shows the consistency check for the entire MSR2 level 2 data set after applying the corrections.

\begin{tabular}{|c|c|c|c|c|c|c|c|}
\hline Name & $\begin{array}{l}\text { RMS } \\
\text { (DU) }\end{array}$ & $\begin{array}{r}\text { Offset } \\
\text { (DU) }\end{array}$ & $\begin{array}{r}\text { Trend } \\
(\text { DU year }\end{array}$ & $\begin{array}{r}\text { VZA } \\
\left(\mathrm{DUdeg}^{-1}\right)\end{array}$ & $\begin{array}{r}\text { SZA-1 } \\
\left(\mathrm{DUdeg}^{-1}\right)\end{array}$ & $\begin{array}{r}\text { SZA-2 } \\
\left(\mathrm{DUdeg}^{-1}\right)\end{array}$ & $\begin{array}{r}T_{\text {eff }} \\
\left(\mathrm{DUK}^{-1}\right)\end{array}$ \\
\hline BUV & 13.35 & 20.00 & 0.81 & N/A & 0.057 & -0.0054 & -0.23 \\
\hline TOMS-N7 & 9.64 & -1.40 & 0.13 & 0.004 & 0.045 & 0.0004 & -0.29 \\
\hline TOMS-EP & 9.40 & 0.49 & 0.49 & 0.021 & 0.125 & -0.0017 & -0.36 \\
\hline SBUV07 & 10.60 & 4.78 & 0.42 & N/A & -0.014 & -0.0001 & -0.18 \\
\hline SBUV09 & 10.46 & -4.63 & -0.37 & N/A & -0.092 & 0.0037 & -0.07 \\
\hline SBUV11 & 10.14 & -1.56 & -0.08 & N/A & -0.023 & 0.0007 & -0.17 \\
\hline SBUV14 & 10.18 & -1.58 & 0.32 & N/A & 0.062 & -0.0017 & -0.16 \\
\hline SBUV16 & 9.71 & -2.87 & 0.41 & N/A & -0.077 & 0.0016 & -0.29 \\
\hline SBUV17 & 10.73 & -1.08 & 0.06 & N/A & 0.029 & -0.0013 & -0.28 \\
\hline SBUV18 & 9.39 & -0.39 & -0.11 & N/A & 0.013 & -0.0010 & -0.33 \\
\hline SBUV19 & 9.51 & -1.05 & 0.09 & N/A & 0.004 & -0.0013 & -0.27 \\
\hline GDP5 & 8.92 & -1.76 & -0.10 & 0.037 & 0.136 & -0.0031 & 0.05 \\
\hline TOGOMI2 & 8.70 & 0.35 & 0.07 & 0.079 & 0.036 & -0.0022 & -0.06 \\
\hline SGP5 & 9.64 & -2.00 & 0.09 & -0.018 & -0.017 & -0.0009 & -0.06 \\
\hline TOSOMI2 & 8.56 & 2.09 & 0.17 & 0.046 & 0.021 & -0.0050 & 0.00 \\
\hline OMDOAO3 & 9.09 & 4.03 & 0.00 & -0.015 & 0.009 & -0.0019 & -0.13 \\
\hline OMTO3 & 7.51 & 3.32 & -0.00 & 0.001 & 0.006 & -0.0006 & -0.27 \\
\hline GOME2 & 8.08 & 4.04 & 0.08 & 0.005 & 0.085 & -0.0048 & -0.17 \\
\hline MSR2 (level 2) & 8.97 & 0.14 & 0.01 & -0.001 & -0.003 & -0.0002 & -0.04 \\
\hline MSR2 (level 2) & 8.97 & 0.14 & 0.01 & -0.001 & -0.003 & -0.0002 & -0.04 \\
\hline
\end{tabular}

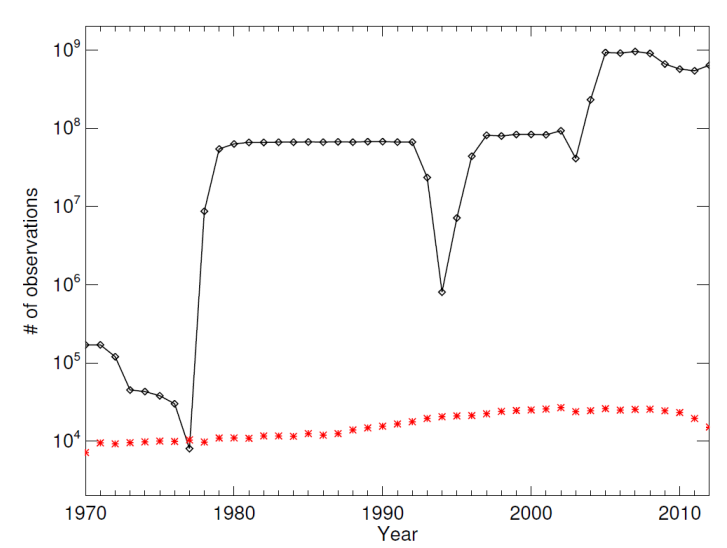

Figure 2. The number of annual satellite observations used in the compilation of the MSR2 (black line and diamonds). Note the logarithmic scale of the $y$ axis. The red asterisks show the number of annual ground-based observations available.

later followed by the start of the observations of GOME-1. In 2003, we see the reduction of GOME-1 measurements due to a malfunctioning tape drive on board the satellite. Thereafter, the number of observations grew due to the launch of the OMI instrument and 3 years later the GOME-2 instrument. The number of observations was slightly reduced beginning in 2008 due to the so-called "row anomaly" in the
OMI instrument. Also shown in Fig. 2 (in red) are the numbers of ground-based observations used for the MSR2. There are lower numbers in ground-based observations for 1970 because the MSR2 starts in April 1970, and at the end of the time series because not all observations were yet submitted to the database.

\subsection{Ground-based data}

Complementary to space observations are routine ozone column observations made at ground stations by the Brewer, Dobson, and Filter instruments (e.g. Fioletov et al., 2008). Apart from their direct use in ozone monitoring (e.g. Staehelin et al., 2001), these observations have been a crucial source of information to test or validate satellite retrievals. Extensive research on the performance of this network has been published by Fioletov et al. (2008). The World Ozone and Ultraviolet Radiation Data Centre (WOUDC) collects these ground-based observations, and makes them available for research. As for the MSR1, only Brewer and Dobson measurements have been used for the MSR2. A temperature correction based on Kerr (2002) of the total ozone amount has been applied to all Dobson total ozone data.

The daily average total ozone observations for each station, in the period 1970-2012, have been extracted. The time resolved observations have not been used, as these are available only for a limited number of stations, thus only Direct- 
Sun data have been used in this study. A "blacklist" has been created that indicates for each year and for each ground station if the data are suspect. Suspect data have been identified by comparison with various satellite data sets. If sudden jumps, strong trends or very large offsets are found, the station is blacklisted. This subjective blacklist is quite similar to the one used by Bodeker et al. (2001). In total $5 \%$ of the ground data has been blacklisted. The ground stations used in this study can be found in Table A2 in the Appendix.

\subsection{Corrections for the satellite data sets}

For long-term accuracy and consistency, it is crucial to reduce offsets, trends and long-term variations in the satellite data so that the data can be used as input to the assimilation scheme with minimised biases and with known standard deviations (SDs). As in MSR1, the parameters fitted to correct for the ozone differences (satellite minus ground-based observation) are the SZA, the VZA, the effective temperature of stratospheric ozone, time and an offset (with reference year 2000). The inclusion of a second-order SZA correction is new compared to the MSR1 correction, since most satellite data sets show a non-linear SZA dependence for low solar elevation angles. A basic assumption is that all corrections are additive to the total ozone amount. By fitting all data together, regional biases that may be caused by offsets of individual ground instruments are avoided. For each satellite product, an "overpass" data set is created for all ground stations and a maximum allowed distance between the centre of the ground pixel and the ground station is defined (see column "Dist." in Table 1). This number is typically $50-200 \mathrm{~km}$ depending on the ground pixel size. These overpass data sets are fitted to the ground data for the five free parameters. The number of overpasses actually used in the regression is shown in the last column of Table 1.

The relevant regression parameters, i.e. those that reduce the RMS (root mean square) between satellite and groundbased observations significantly, and the corresponding coefficients are shown in Table 2. The TOMS-EP data set is corrected for a trend for the last 2 years only, so this data set is divided in two. The data sets that show a non-linear dependence on VZA are corrected on a "per pixel" basis. Note that the (S)BUV instruments perform only nadir measurements and the VZA dependence is therefore absent.

Based on the calculated corrections the merged MSR2 level 2 data set is created. The original satellite data sets were read, filtered for bad data, corrected according to the corrections listed in Table 2, and finally merged into a single timeordered data set. Essential information in the MSR2 level 2 data set is time, location, satellite ID and ozone. In the data assimilation the satellite ID is used to assign a corresponding measurement error to this observation. After applying this bias correction procedure, the trend, offset, and seasonal cycle in the satellite observations were reduced to a negligible level in the MSR2 level 2 data as shown in the last line of Table 2.

\section{Ozone model and data assimilation}

The chemistry transport model used is a simplified version of TM5 (Krol et al., 2005; Huijnen et al., 2010), which is driven by ECMWF analyses of wind, pressure and temperature fields. The model uses only one tracer for ozone and a parameterization for the chemical modelling. The assimilation approach is an extension of the work described in Eskes et al. (2003). As input, the assimilation uses ozone column values and estimates of the measurement uncertainty. The ozone model setup and data assimilation scheme in TMDAM have been described in van der A et al. (2010), and we refer to this paper for more details. For the MSR2 several improvements have been implemented, which are described below.

The model resolution of TMDAM and its output are upgraded from $2^{\circ} \times 3^{\circ}$ to $1^{\circ} \times 1^{\circ}$. The model is driven by 3 hourly meteorological fields extracted at $1^{\circ} \times 1^{\circ}$ from ERAInterim (Dee et al., 2011) reanalysis of ECMWF, available for the period 1979-2012. Assimilation in MSR1 was based on ERA-40 and operational ECMWF data (from 2002 onwards) at $6 \mathrm{~h}$ resolution. ERA-Interim provides an improved representation of the meteorology and is one consistent data set for the entire period after 1979. For the period before 1979, ERA-Interim is not available and the ERA-40 reanalysis at $2^{\circ} \times 3^{\circ}$ resolution is used. The data assimilation for this period is also performed on a $2^{\circ} \times 3^{\circ}$ grid. The 60 ECMWF hybrid layers between $0.01 \mathrm{hPa}$ and the surface have been converted into 44 layers used in TMDAM, whereby in the stratosphere and upper troposphere all levels are identical to the ECMWF levels. The ozone column output of the TMDAM analyses is stored with a resolution of $1 / 2^{\circ} \times 1 / 2^{\circ}$, using the subgrid gradient information from the secondorder moments advection scheme (Prather, 1986). The stratospheric ozone chemistry in TMDAM is described by the Cariolle parameterisation (Cariolle and Teyssèdre, 2007), which has been updated from version 2.1 in MSR1 to version 2.9 in MSR2. The error correlation between individual measurements of different instruments or algorithms is set to zero, while the correlation between measurements of the same instrument is assumed to be $50 \%$ following Eskes et al. (2003). The processing speed of the analysis step has been improved by a factor of 20-60 due to several optimisations in the code.

The quality control consists of a comparison between the individual observations and the model forecast, or OmF. When the OmF exceeded 3 times the square root of the forecast variance plus the observation variance, the observation was rejected. Only a few percent of all observations are rejected with this quality check. 
The 6-hourly instantaneous and monthly mean ozone fields of the MSR2 are available on the TEMIS website, http: //www.temis.nl/. For UV radiation studies, the daily ozone fields at local noon are also made available on this website.

\section{Data assimilation results and error analysis}

\subsection{Time series of the MSR2}

Figure 3 shows the annual mean total ozone over De Bilt (left) and the 3-month (September-November) mean ozone column below $60^{\circ} \mathrm{S}$ (right). The period covered by the MSR2 shows the beginning of the ozone hole in the 1980s when chlorofluorocarbons (CFCs) were increasing in the stratosphere and the more or less stable period afterwards when the Montreal Protocol was implemented and CFCs started their slow decline. For reference, the 11-year running mean of ozone is plotted (green line). The annual mean Brewer total ozone for De Bilt that started in 1996 has been added. In the right plot, a large difference between MSR1 and MSR2 is visible for the year 1993, when only data from SBUV is available. In the MSR2 data the error criteria are slightly stricter resulting in more missing data for September 1993. This leads to an underestimation of the 3-month average in that year.

\subsection{Error analysis}

The total ozone data are assimilated by applying a parameterized Kalman filter technique. In this approach the forecast error covariance matrix is written as a product of a time independent correlation matrix and a time dependent diagonal variance. The various parameters in this approach are fixed and are based on the observation-minus-forecast (OmF) statistics accumulated over the period of 1 year (2000) using GOME observations. This method produces detailed and realistic time- and space-dependent forecast error distributions. To check if these parameters are still valid for the MSR2 in other years, we have compared the observed OmF (by comparing the forecast with individual observations) with the estimate of the OmF. The latter is calculated from the combination of the model forecast error as computed in TMDAM and the given individual measurement error bars on the observations. This approach can be seen as an extension of the much-used $\chi^{2}$ test, which essentially checks if the mean of both quantities are consistent. In Fig. 4 we show this comparison for two extreme cases in the MSR2 time series, the first for the complete year 1971 (see Fig. 4a) when only the sparse BUV observations were available, and the second for 30 April 2010 (see Fig. 4b) when there is a very high density of observations from a wide range of satellite instruments. The grey area shows the number of observations with that specific forecasted OmF. The black line indicates the perfect situation where the observed $\mathrm{OmF}$ in the bin would be equal to the forecasted OmF. As one can see from the figures, in both cases the OmF values are remarkably comparable, especially in the grey area corresponding to the bulk of observations. Based on these results we decided that no changes were needed for the model error parameters in the Kalman filter as compared to MSR1. The OmF is much smaller for the more modern satellite instruments in 2010, mainly because of the higher number of observations per model grid cell and the daily revisit cycle.

The error field is an important component of the assimilation process and determines the relative contribution of the observations and model to the analysed ozone amount, as prescribed by the analysis equation of the Kalman filter which leads to a reduction of the error of the model distribution close to the observations. Between successive measurements the error variance grows due to the model error, and the variance field is advected in the same way as ozone itself (van der A et al., 2010). Those three aspects of the time dependence of the error field can be recognised in Fig. 5. Since the number of observations is much higher in 2006 (and available for more locations) the error is in general much lower. Since no observations over the Antarctic exist in summertime (right figure), the error is much higher, although it is partly reduced by the advection of ozone into this region.

\subsection{OmF statistics}

To evaluate the performance of the MSR2 we routinely produce $\mathrm{OmF}$ and observation-minus-analysis (OmA) statistics. These statistics provide an internal consistency check on the error estimates for the total ozone retrieval as well as for the model performance. In the data assimilation the forecasts are calculated in sequential steps of half an hour. For the assimilation of observations of a single sensor with full daily coverage, the observations at a certain location are typically available once a day and therefore the OmF statistics result from an unconstrained model forecast time step of roughly 1 day. Smaller time steps occur near the poles. For the assimilation of SBUV observations only the revisit time is typically 1 week, given that the assimilation has a spatial correlation length of $500 \mathrm{~km}$. For the assimilation of data from multiple sensors this is different, and time steps between observations vary from half an hour to 1 day. In this case the OmF, OmA and ozone assimilation results are more constrained by the observations. Typical OmF and OmA behaviour that has been confirmed are (i) in general the OmA must be smaller than the OmF, (ii) no significant geo-location or geo-parameter dependencies should be visible.

In Fig. 6 the OmF is shown as function of the geoparameters solar zenith angle, latitude, cloud fraction and viewing angle for January 2008. In addition the RMS values of the OmF and OmA are plotted in the figure. The systematic effects found for these parameters are all much smaller than the typical RMS. On average the RMS difference between new satellite observations and the short-range model forecast ( 1 day) is small; about $6 \mathrm{DU}$, or roughly $2 \%$ 

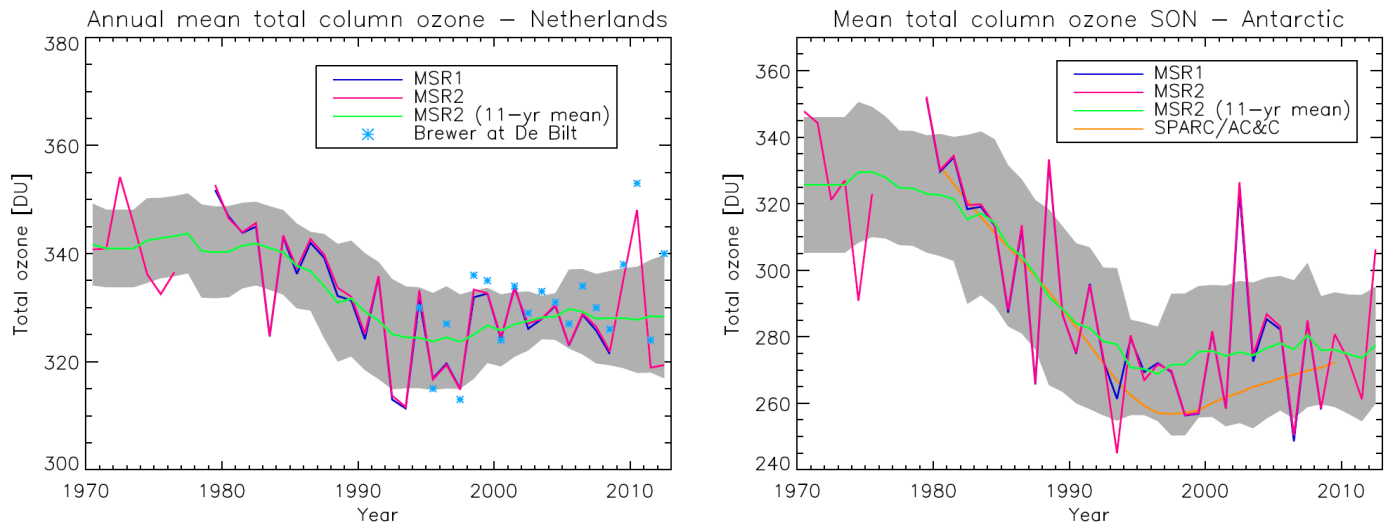

Figure 3. Mean ozone values for the period 1970-2012 above De Bilt ( $\left.5.18^{\circ} \mathrm{E}, 52.1^{\circ} \mathrm{N}\right)$ (left, annual mean) and the Antarctic (right, mean of September-November). The blue line shows the results for MSR1, the red line for MSR2, the grey area shows the variability of the monthly means within a year (left) or 3 months (right). The green line presents an 11-year running mean for de Bilt (left) and the orange line shows the model values of SPARC/AC\&C (Cionni et al., 2011) for Antarctic (right).
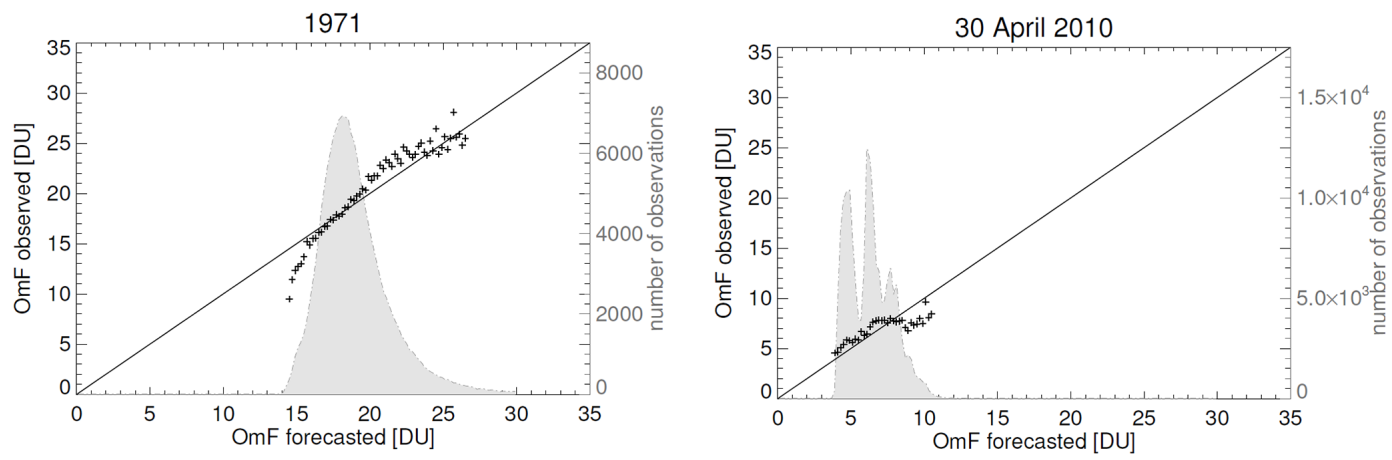

Figure 4. OmF (observation-minus-forecast) from the data assimilation as a function of the theoretical OmF as calculated from model error and the individual measurement errors. The grey area and $y$ axis on the right indicate the number of observations per OmF value (bin size is $0.2 \mathrm{DU})$.

for this month. The RMS error of the OmF is smaller than the observational error compared to ground-based observations, because representative errors of the satellite observations compared to level 4 data are likely to be smaller than for satellite observations compared to ground-based observations. For high solar zenith angles the RMS value increases, because these measurements are usually associated with the highly variable ozone concentrations in and around the polar vortex. Plots similar to Fig. 6 show that the bias between the forecast and the satellite columns is generally smaller than $1 \%$ after 1979 . The bias between analyses and observations is in general even smaller (less than $1 \mathrm{DU}$ ), which shows the effect of data assimilation. Compared to the MSR1 results (van der A et al., 2010), the bias is slightly decreased probably as a result of the higher spatial resolution for the MSR2, the improved data assimilation and the improved solar zenith angle correction.

Figure 7 is similar to Fig. 6 but here the statistics are for the year 1971, when only BUV observations were available. In this period the time between observations of the same air mass is generally much longer than 24 hours. There is no plot as a function of viewing angle since BUV was observing under a fixed angle in nadir direction. The mean $\mathrm{OmF}$ and OmA values are in general still small (less than $5 \%$ ), but the RMS values are higher than after 1979, reaching up to $10 \%$. A region in the Southern Hemisphere shows a high forecast error, especially visible in the plot as function of latitude. This is because all BUV data in and around the South Atlantic Anomaly have not been made available and therefore the forecasts involve longer time steps. The structures seen in the latitude dependence in Fig. 7 reflect the ozone model errors (drifts), which may be related to issues with the ERA40 meteorology, mainly in the tropics (Uppala et al., 2005), and the removal of BUV data in the South Atlantic Anomaly region.

Figure 8 shows an example of the OmF gridded for January 2008 as function of geographical location. In general the mean $\mathrm{OmF}$ is between -3 and $+3 \mathrm{DU}$. In the northern latitudes, some higher variations are found to be caused by the vicinity of the polar night where observations are lacking. 

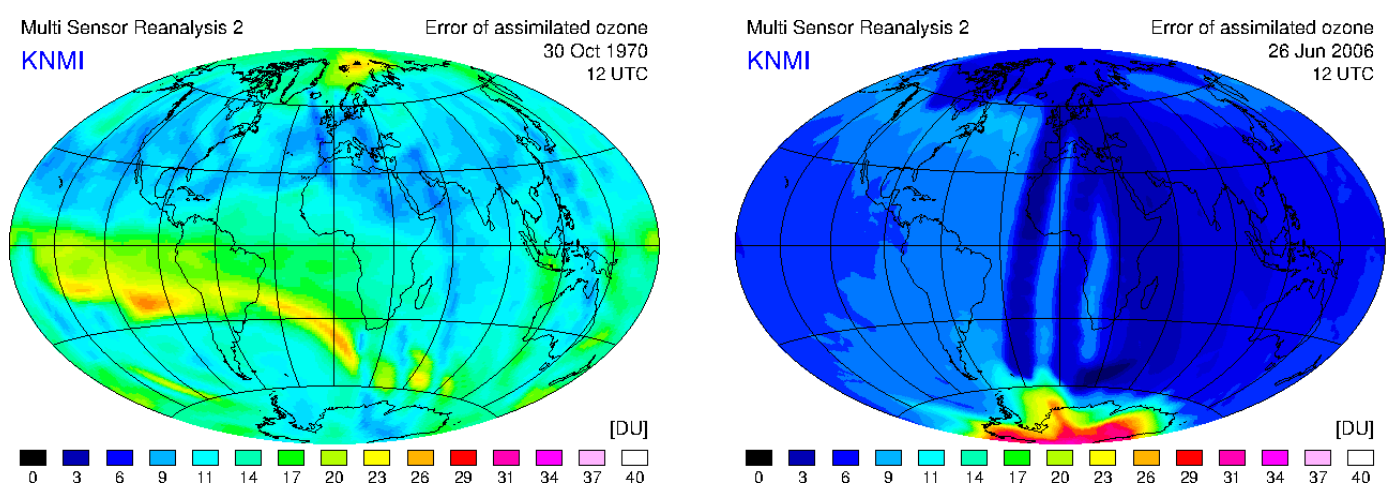

Figure 5. The instantaneous error field during the assimilation of the ozone data for the MSR2 at 12:00 UTC on 30 October 1970 (left panel) when satellite data are sparse and on 26 June 2006 (right panel) when the number of satellite observations is more or less at its peak. The location of the most recent assimilated measurements coincides with the lowest errors. The model error term leads to an increase of the forecast error with the time passed since the last analysis. The advection of the error is visible as distortions of the orbit shape.
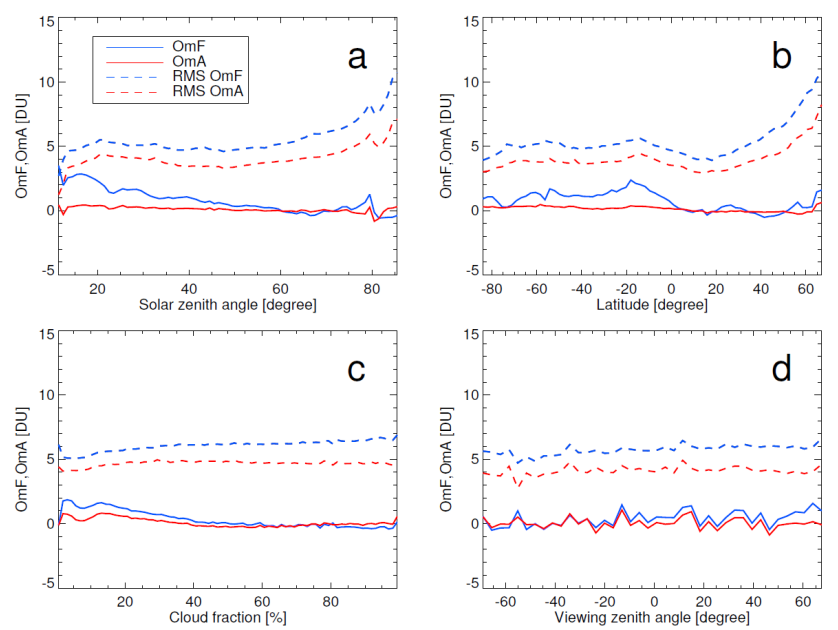

Figure 6. The OmF in Dobson units (blue line) and the OmA (red line) as a function of solar zenith angle (a), latitude (b), cloud fraction (c), and viewing zenith angle (d). The dashed lines represent the RMS value of the OmF (blue) and the OmA (red) distribution. All data are averaged over January 2008.

No obvious patterns as functions of ground elevation or surface type are visible. For this month a small bias of 1-2 DU is visible between the Northern and Southern Hemisphere. Compared to the OmF of the MSR1 data set the deviations are somewhat smaller. The MSR1 shows more pronounced small scale structures with sizes of the order of $500 \mathrm{~km}$.

\subsection{Validation with ground-based observations}

The corrections for the satellite retrieval data sets have been derived from comparisons with all stations simultaneously and are not latitude or station dependent. This implies that the individual ground-based observations can still be used for the evaluation of the final MSR2 ozone record. The geographical distribution of the offset between MSR2 data and individual
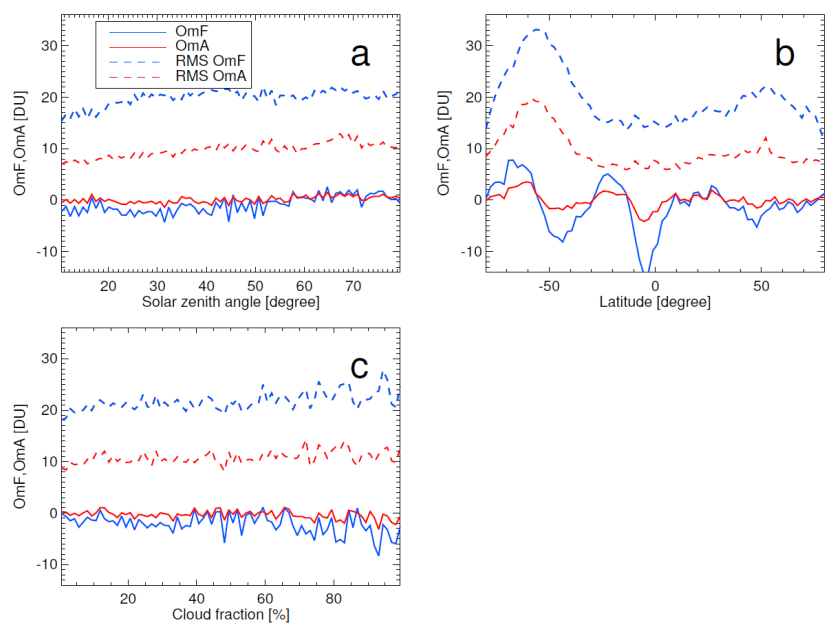

Figure 7. Same as Fig. 6, but no panel (d). There is no change in viewing angles in this period, because BUV has only nadir observations. All data are averaged over 1971.

ground stations is shown in Fig. 9. On average, the offset is small, and only a few outlier stations are visible, often close to a station with a very small offset which suggests that the offset is station related. No systematic structures are obvious in the geographical distribution.

Another important aspect of the performance of the data assimilation is the vertical distribution of ozone in the model. Although the data assimilation is analysing total columns, the model describes the vertical distribution of ozone and an update of the total ozone is distributed over the vertical profile by scaling the modelled profile to have the same total ozone. If this profile shape deteriorates, this will also affect the quality of the analysed ozone columns. We have checked the ozone distribution in different years by comparing with ozone sondes from the WOUDC archive. No significant drift in the ozone profile shape was visible over a time period of 

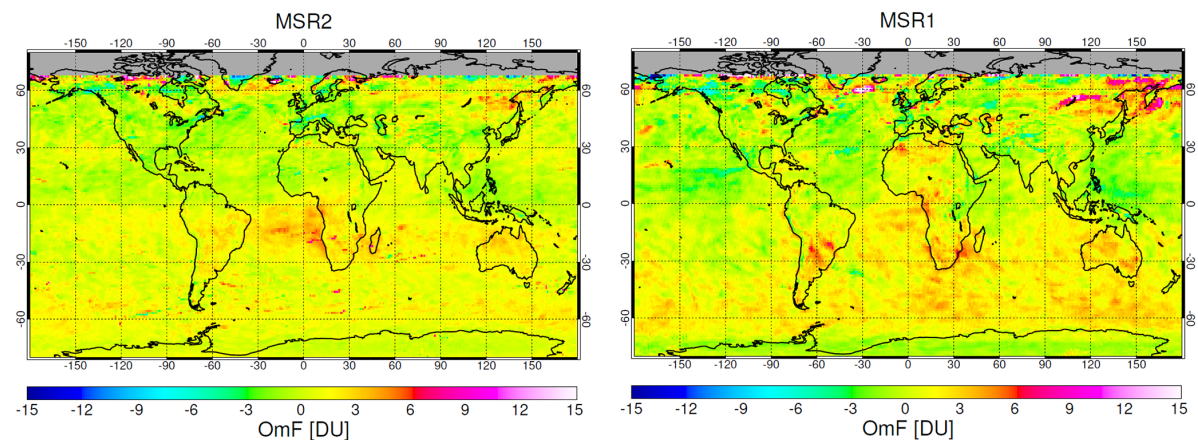

Figure 8. The global distribution, gridded on $1^{\circ} \times 1^{\circ}$, of the OmF in Dobson units of the MSR2 data set averaged for the month January 2008 (left panel). The MSR2 data for this month are based on satellite observations from SBUV, GOME, SCIAMACHY, GOME2 and OMI. The right panel shows the same OmF distribution for the MSR1.

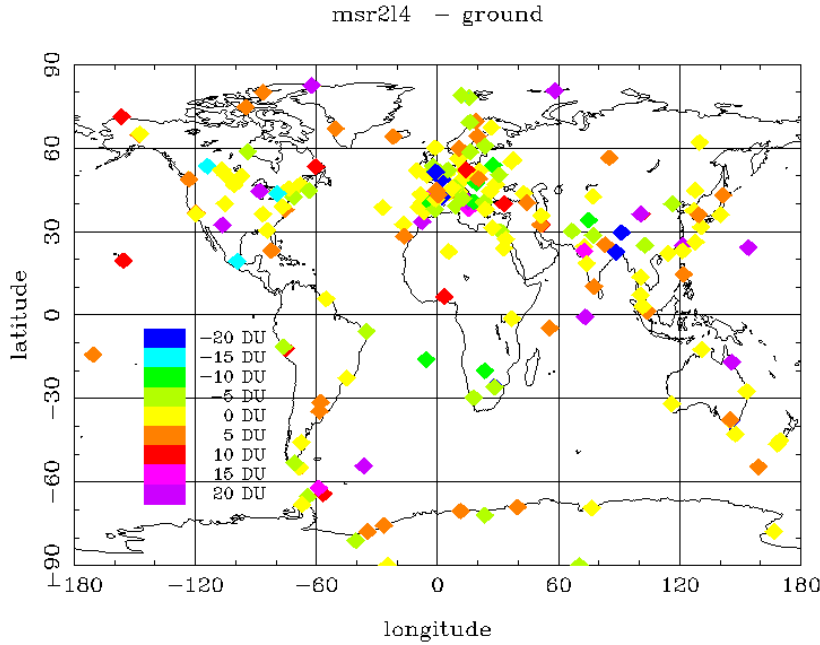

Figure 9. Mean offset (MSR2 minus ground-based) between the MSR2 level 4 data and all selected Dobson and Brewer groundbased measurements in the period 1970-2012.

10 years of assimilating ozone columns. As can be seen in Fig. 10, the bias between ozone sondes and the model ozone profiles is less than $10-20 \%$, which is satisfactory, given that the ozone profile is not constrained by observations. These relatively small profile biases will not significantly impact the ozone column analysis, as demonstrated by the good performance of the assimilation system.

\section{Concluding remarks}

The Ozone Multi-Sensor Reanalysis version 2 (MSR2) provides a 43-year long-term (climate) data record of highresolution global distributions of total ozone with 6-hourly sampling. Detailed time and space dependent forecast error fields are provided together with the ozone fields. The data are created in two steps: First, small systematic biases in the satellite data are corrected by using average Brewer and Dobson ground-based observation as a reference. Secondly, all

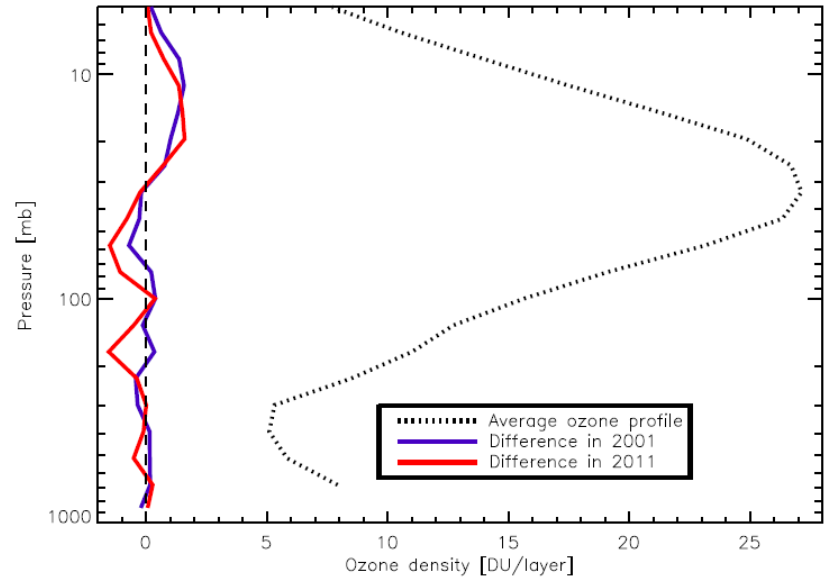

Figure 10. Validation of the ozone distribution in the model using a selection of about $30-40$ ozone sonde stations. The mean difference between the sonde and MSR2 ozone profile is shown for 2001 (blue) and 2011 (red). For reference the average ozone profile of the sondes is shown (dotted line).

satellite data are assimilated with a Kalman filter technique in order to create a consistent data record with a regular spatial grid of $1^{\circ} \times 1^{\circ}$. The data set is based on the observations of 15 different satellite instruments with observations in the UV.

For the new MSR2 data set, improvements are made to the calculation of correlations between the observations and the Cariolle parameterisation for chemistry modelling has been upgraded. The calculation speed has been optimised to be able to perform data assimilation at the increased resolution of $1^{\circ} \times 1^{\circ}$.

The parameterized estimated error on the ozone column computed in the data assimilation has been shown to be accurate for all time periods, even when observational data are sparse. It was shown that the Kalman filter predicted OmF SD, based on the measurement errors and the estimated model forecast errors, is generally close to the mean SD of 
the observed OmF departures. As an internal consistency check, the MSR2 level 2 and level 4 data have been compared to ground-based observations with satisfying results.

To evaluate the quality of the MSR2 data, the OmF and OmA statistics have been analysed. The OmA of this data set is less than $1 \%$, which is better than for the assimilation of observations of a single sensor and is improved as compared to the MSR1. The model bias as estimated by the difference between OmF and OmA is in general small: for periods of a couple of days with no data, the bias remains within $1 \%$. As discussed, this holds also for the period with only sparse BUV observations, although model biases of several percent as a function of latitude become visible. The RMS errors are around 2-3\% between 1979 and 2012, which is small given that the RMS errors contain contributions from the representativity errors, forecast errors and instrumental noise. For very long time periods without any data (e.g. in 1977), longer than several months, the error becomes more than $20 \%$. These cases may be efficiently excluded from the data set by filtering with the forecast error estimate provided in the ozone data product, which correctly indicates large model forecast errors during these periods.

It has been shown that the MSR2 level 2 data show insignificant drift and SZA and effective ozone temperature dependence as compared to the ground-based observations (see Table 2). The fitted offset, trend and seasonality in the comparison between the MSR2 level 4 ozone fields and the average of the ground-based observations were negligible. The maximum fitted offset is $0.2 \mathrm{DU}$. All systematic effects found in the satellite data are removed by the simple corrections (using a few basic parameters) applied to the satellite observations in the period 1970-2012.
The availability of reprocessed BUV total ozone measurements made it possible to extend our data series into the 1970s. Unfortunately, the BUV observations are not available for the complete period of 1970-1978 and a large part of the data on the Southern Hemisphere has been filtered because of interference from the South Atlantic Anomaly (SAA). This means that part of the MSR2 data in the 1970s strongly depend on the model performance. To improve upon this, the Dobson ground-based measurements may be assimilated together with the BUV satellite observations during the 1970s. This combined assimilation is very likely to improve the analysed ozone distributions significantly, especially in the SAA region and in the periods without any satellite data (summer 1976 and 1977). For a future extension of the MSR2, we expect to have many satellite observations available, especially from the planned operations of GOME2 on METOP-C and -D, from OMPS and from the European Sentinel missions. 


\section{Appendix A}

Table A1. List of ground stations used in this study, showing the WMO number of the station and its name.

\begin{tabular}{|c|c|c|c|c|c|c|c|}
\hline No. & Station name & No. & Station name & No. & Station name & No. & Station name \\
\hline 002 & Tamanrasset & 091 & Buenos Aires & 207 & Mahe (Seychelles) & 320 & Winnipeg \\
\hline 003 & Almaty & 092 & Hobart & 208 & Xianghe & 321 & Halifax (Bedford) \\
\hline 005 & Dikson Island & 095 & Taipei & 209 & Kunming & 322 & Petaling Jaya \\
\hline 007 & Kagoshima & 096 & Hradec Kralove & 211 & King Edward Point & 324 & Scott Base \\
\hline 008 & Kodaikanal & 097 & Magny-les-Hameaux & 213 & El Arenosillo & 326 & Long Fengshan \\
\hline 009 & Mount Abu & 098 & Val Joyeaux & 214 & Singapore & 327 & Angra do Heroismo \\
\hline 010 & New Delhi & 099 & Hohenpeissenberg & 216 & Bangkok & 331 & Poprad-Ganovce \\
\hline 011 & Quetta & 100 & Budapest-Lorinc & 217 & Poker Flat & 332 & Pohang \\
\hline 012 & Sapporo & 101 & Syowa & 218 & Manila & 336 & Isfahan \\
\hline 013 & Srinagar & 102 & Bracknell & 219 & Natal & 338 & Bratt's Lake (Regina) \\
\hline 014 & Tsukuba & 104 & Bedford & 222 & Maputo & 339 & Ushuaia \\
\hline 016 & Vladivostok & 105 & Fairbanks & 223 & Nampula & 340 & Springbok \\
\hline 018 & Alert & 106 & Nashville & 226 & Bucharest & 341 & Hanford \\
\hline 019 & Bismarck & 107 & Wallops Island & 232 & Faraday/Vernadsky & 342 & Comodoro Rivadavia \\
\hline 020 & Caribou & 110 & Huancayo & 233 & Marambio & 343 & Salto \\
\hline 021 & Edmonton & 111 & Amundsen-Scott & 241 & Saskatoon & 345 & Songkhla \\
\hline 022 & Green Bay & 112 & Bolshaya Elan & 243 & Brindisi & 346 & Murcia \\
\hline 024 & Resolute & 113 & Dushanbe & 244 & Fresno & 347 & Issyk-Kul \\
\hline 026 & Aspendale & 114 & Heiss Island & 245 & Aswan & 348 & Ankara \\
\hline 027 & Brisbane & 115 & Samara & 252 & Seoul & 349 & Lhasa \\
\hline 028 & Dumont d'Urville & 116 & Moscow & 253 & Melbourne & 351 & King George Island \\
\hline 029 & Macquarie Island & 117 & Murmansk & 256 & Lauder & 352 & Manchester \\
\hline 030 & Minamitorishima & 118 & Nagaevo & 261 & Thessaloniki & 353 & Reading \\
\hline 031 & Mauna Loa & 119 & Odessa & 262 & Sodankyla & 354 & Minsk \\
\hline 032 & Wellington & 120 & Omsk & 265 & Irene & 376 & Mersa Matruh \\
\hline 033 & Abastumani & 121 & Riga & 267 & Sondrestrom & 394 & Broadmeadows \\
\hline 034 & Aarhus & 122 & Yekaterinburg & 268 & Arrival Heights & 399 & Ushuaia II \\
\hline 035 & Arosa & 123 & Yakutsk & 271 & Arkhangelsk & 400 & Maitri \\
\hline 036 & Camborne & 124 & Cerrillos & 272 & Volgograd & 404 & Jokioinen \\
\hline 038 & Cagliari/Elmas & 128 & Karaganda & 273 & Kotelny Island & 405 & La Coruna \\
\hline 040 & Haute Provence & 129 & Pechora & 274 & Nikolayevsk-on-Amur & 406 & Scoresby Sund \\
\hline 042 & St. Petersburg & 130 & Petropavlovsk & 275 & Skovorodino & 407 & Zhigansk \\
\hline 043 & Lerwick & 142 & Igarka & 276 & Tura & 409 & Hurghada \\
\hline 044 & Longyear & 143 & Krasnoyarsk & 277 & Tsimlyansk & 410 & Amberd \\
\hline 045 & Messina & 144 & Markovo & 278 & Cardzou & 411 & Zaragoza \\
\hline 047 & Naples & 145 & Olenek & 279 & Norrkoeping & 419 & Bordeaux \\
\hline 048 & Oxford & 147 & Semipalatinsk & 280 & Novolazarevskaya & 426 & San Julian \\
\hline 050 & Potsdam & 148 & Vitim & 281 & Vostok & 427 & Doctor Sobral \\
\hline 051 & Reykjavik & 150 & Khanty Mansiysk & 282 & Kislovodsk & 429 & Marcapomacocha \\
\hline 052 & Troms $\emptyset$ & 152 & Cairo & 284 & Vindeln & 435 & Paramaribo \\
\hline 053 & Uccle & 153 & Voronezh & 285 & Cape Kaliakra & 436 & La Reunion Island \\
\hline 055 & Vigna di Valle & 155 & White Sands & 286 & Primorsko & 442 & Pilar \\
\hline 057 & Halley & 158 & Casablanca & 287 & Funchal (Madeira) & 446 & Bauru \\
\hline 062 & Port aux Francais & 159 & Perth & 288 & Penhas Douradas & 447 & Goddard \\
\hline 065 & Toronto & 165 & Oslo & 290 & Saturna Island & 454 & San Martin \\
\hline 067 & Boulder & 174 & Lindenberg & 291 & Asquith (Grandora) & 455 & Chisinau \\
\hline 068 & Belsk & 175 & Nairobi & 293 & Athens & 464 & University of Tehran \\
\hline 070 & Mont louis & 180 & Invercargill & 295 & Mt. Wa Liguan & 467 & Maun \\
\hline 071 & Pretoria & 182 & Aralskoe More & 298 & Aleppo & 468 & Cape d'Aguilar \\
\hline 073 & Ahmedabad & 183 & Atiray (Gurev) & 300 & Izana (Tenerife) & 473 & Punta Arenas \\
\hline 074 & Varanasi & 184 & Lviv & 301 & JRC Ispra (Varese) & 474 & Lannemezan \\
\hline 075 & Dum Dum & 185 & Tbilisi & 304 & Gonghe & 476 & Andoya \\
\hline 076 & Goose Bay & 186 & Tiksi & 305 & Rome University & 478 & Zhongshan \\
\hline 077 & Churchill & 187 & Poona/Pune & 306 & Cheng Kung & 479 & Aosta \\
\hline 079 & Tallahassee & 189 & Svalbard Hornsund & 307 & Obninsk & 481 & Tomsk \\
\hline 080 & Gan & 190 & Naha & 308 & Madrid & 492 & Concordia \\
\hline 082 & Lisbon & 191 & Samoa & 311 & Havana & 493 & Rio Gallegos \\
\hline 084 & Darwin & 192 & Mexico city & 312 & Kaunas & 497 & Tarawa \\
\hline 085 & Irkutsk & 193 & Cairns & 314 & Belgrano II & 498 & Kiev-Goloseyev \\
\hline 086 & Feodosiya & 197 & Biscarrosse/SMS & 315 & Eureka & 499 & Princess Elisabeth \\
\hline 087 & Kiev & 199 & Barrow & 316 & De Bilt & 512 & Toronto \\
\hline 088 & Mirny & 200 & Cachoeira Paulista & 317 & Lagos & & \\
\hline 089 & Ny Alesund & 201 & Sestola & 318 & Valentia Observatory & & \\
\hline 090 & Ashgabat & 204 & St. Helena & 319 & Montreal (Dorval) & & \\
\hline
\end{tabular}


Table A2. The satellite data sets used in this study. The columns show the name of the data set, the satellite instrument on which it is based, the satellite, the algorithm version used and the responsible agency for this data set.

\begin{tabular}{lllll}
\hline Name & Instrument & Satellite & Algorithm version & Agency \\
\hline BUV & BUV & Nimbus-4 & BUV v.8.6 (L2.2.01) & NOAA/NASA \\
TOMS-N7 & TOMS & Nimbus-7 & TOMS v. 8 & NASA \\
TOMS-EP & TOMS & Earth probe & TOMS v. 8 & NASA \\
SBUVN07 & SBUV & Nimbus-7 & SBUV v.8.6 & NOAA/NASA \\
SBUVN09 & SBUV/2 & NOAA-9 & SBUV v.8.6 & NOAA/NASA \\
SBUVN11 & SBUV/2 & NOAA-11 & SBUV v.8.6 & NOAA/NASA \\
SBUVN14 & SBUV/2 & NOAA-14 & SBUV v.8.6 & NOAA/NASA \\
SBUVN16 & SBUV/2 & NOAA-16 & SBUV v.8.6 & NOAA/NASA \\
SBUVN17 & SBUV/2 & NOAA-17 & SBUV v.8.6 & NOAA/NASA \\
SBUVN18 & SBUV/2 & NOAA-18 & SBUV v.8.6 & NOAA/NASA \\
SBUVN19 & SBUV/2 & NOAA-19 & SBUV v.8.6 & NOAA/NASA \\
GDP5 & GOME-1 & ERS-2 & GDP 5. & DLR/ESA \\
TOGOMI2 & GOME-1 & ERS-2 & TOGOMI v.2. & KNMI/ESA \\
SGP5 & SCIAMACHY & Envisat & SGP v.5.02W & DLR/ESA \\
TOSOMI2 & SCIAMACHY & Envisat & TOSOMI v.2. & KNMI/ESA \\
OMDOAO3 & OMI & Aura & OMDOAO3 & KNMI \\
OMTO3 & OMI & Aura & OMTO3 & NASA \\
GOME2A & GOME-2 & Metop-A & GDP4.6 & DLR/EUMETSAT \\
\hline
\end{tabular}


Acknowledgements. The authors would like to thank Pieter Valks for providing us the GOME-2 ozone column data. The authors thank WMO-GAW, the WOUDC and the ground station operators for providing the ozone column data at http://www.woudc.org/. Furthermore, the authors thank the agencies NASA, NOAA, ESA, and EUMETSAT for making, respectively, TOMS and OMI, SBUV, GOME and SCIAMACHY, and GOME-2 data publically available on their websites.

Edited by: M. Weber

\section{References}

Antón, M., Kroon, M., López, M., Vilaplana, J. M., Bañón, M., van der A, R., Veefkind, J. P., Stammes, P., and Alados-Arboledas, L.: Total ozone column derived from GOME and SCIAMACHY using KNMI retrieval algorithms: validation against Brewer measurements at the Iberian Peninsula, J. Geophys. Res., 116, D22303, doi:10.1029/2011JD016436, 2011.

Bhartia, P. K. and Wellemeyer, C.: TOMS-V8 total $\mathrm{O}_{3}$ algorithm, in: OMI Algorithm Theoretical Basis Document, vol. II, OMI Ozone Products, ATBD-OMI-02, edited by: Bhartia, P. K., NASA Goddard Space Flight Cent., Greenbelt, Md, 15-31, 2002.

Bhartia, P. K., McPeters, R. D., Flynn, L. E., Taylor, S., Kramarova, N. A., Frith, S., Fisher, B., and DeLand, M.: Solar Backscatter UV (SBUV) total ozone and profile algorithm, Atmos. Meas. Tech., 6, 2533-2548, doi:10.5194/amt-6-2533-2013, 2013.

Bodeker, G. E., Scott, J. C., Kreher, K., and McKenzie, R. L.: Global ozone trends in potential vorticity coordinates using TOMS and GOME intercompared against the Dobson network: 1978-1998, J. Geophys. Res., 106, 23029-23042, 2001.

Bovensmann, H., Burrows, J. P., Buchwitz, M., Frerick, J., Noël, S., Rozanov, V. V., Chance, K. V., and Goede, A. P. H.: SCIAMACHY: mission objectives and measurement modes, J. Atmos. Sci., 56, 127-150, 1999.

Brönnimann, S., Staehelin, J., Farmer, S. F. G., Cain, J. C., Svendby, T., and Svenøe, T.: Total ozone observations prior to the IGY, I: a history, Q. J. Roy. Meteor. Soc., 129, 2797-2817, doi:10.1256/qj.02.118, 2003.

Brunner, D., Staehelin, J., Künsch, H.-R., and Bodeker, G. E.: A Kalman filter reconstruction of the vertical ozone distribution in an equivalent latitude-potential temperature framework from TOMS/GOME/SBUV total ozone observations, J. Geophys. Res., 111, D12308, doi:10.1029/2005JD006279, 2006.

Burrows, J. P., Weber, M., Buchwitz, M., Rozanov, V., LadstätterWeißenmayer, A., Richter, A., De Beek, R., Hoogen, R., Bramstedt, K., Eichmann, K. U., Eisinger, M., and Perner, D.: The Global Ozone Monitoring Experiment (GOME): mission concept and first scientific results, J. Atmos. Sci., 56, 151-175, 1999.

Callies, J., Corpaccioli, E., Eisinger, M., Hahne, A., Lefebvre, A.: GOME-2 - Metop's second generation sensor for operational ozone monitoring, ESA Bull.-Eur. Space, 102, 28-36, 2000.

Cariolle, D. and Teyssèdre, H.: A revised linear ozone photochemistry parameterization for use in transport and general circulation models: multi-annual simulations, Atmos. Chem. Phys., 7, 21832196, doi:10.5194/acp-7-2183-2007, 2007.
Chehade, W., Weber, M., and Burrows, J. P.: Total ozone trends and variability during 1979-2012 from merged data sets of various satellites, Atmos. Chem. Phys., 14, 7059-7074, doi:10.5194/acp14-7059-2014, 2014.

Cionni, I., Eyring, V., Lamarque, J. F., Randel, W. J., Stevenson, D. S., Wu, F., Bodeker, G. E., Shepherd, T. G., Shindell, D. T., and Waugh, D. W.: Ozone database in support of CMIP5 simulations: results and corresponding radiative forcing, Atmos. Chem. Phys., 11, 11267-11292, doi:10.5194/acp11-11267-2011, 2011.

Coldewey-Egbers, M., D. Loyola, P. Braesicke, M. Dameris, M. van Roozendael, C. Lerot, and W. Zimmer: A new health check of the ozone layer at global and regional scales, Geophys. Res. Lett., 41, 4363-4372, doi10.1002/2014GL060212, 2014.

Dee, D. P., Uppala, S. M., Simmons, A. J., Berrisford, P., Poli, P., Kobayashi, S., Andrae, U., Balmaseda, M. A., Balsamo, G., Bauer, P., Bechtold, P., Beljaars, A. C. M., van de Berg, L., Bidlot, J., Bormann, N., Delsol, C., Dragani, R., Fuentes, M., Geer, A. J., Haimberger, L., Healy, S. B., Hersbach, H., Hólm, E. V., Isaksen, L., Kållberg, P., Köhler, M., Matricardi, M., McNally, A. P., Monge-Sanz, B. M., Morcrette, J.-J., Park, B.K., Peubey, C., de Rosnay, P., Tavolato, C., Thépaut, J.-N., and Vitart, F.: The ERA-Interim reanalysis: configuration and performance of the data assimilation system, Q. J. Roy. Meteor. Soc., 137, 553-597, doi:10.1002/qj.828, 2011.

de Laat, A. T. J., van der A, R. J., and van Weele, M.: Tracing the second stage of ozone recovery in the Antarctic ozone-hole with a "big data" approach to multivariate regressions, Atmos. Chem. Phys., 15, 79-97, doi:10.5194/acp-15-79-2015, 2015.

den Outer, P. N., van Dijk, A., Slaper, H., Lindfors, A. V., De Backer, H., Bais, A. F., Feister, U., Koskela, T., and Josefsson, W.: Applying spaceborne reflectivity measurements for calculation of the solar ultraviolet radiation at ground level, Atmos. Meas. Tech., 5, 3041-3054, doi:10.5194/amt-5-3041-2012, 2012.

Dethof, A. and Hólm, E. V.: Ozone assimilation in the ERA-40 reanalysis project, Q. J. Roy. Meteor. Soc., 130, 2851-2872, doi:10.1256/qj.03.196, 2004.

Eskes, H. J., van Velthoven, P. F. J., Valks, P. J. M., and Kelder, H. M.: Assimilation of GOME total ozone satellite observations in a three-dimensional tracer transport model, Q. J. Roy. Meteor. Soc., 129, 1663-1681, 2003.

Eskes, H., Segers, A., and van Velthoven, P.: Ozone forecasts of the stratospheric polar vortex splitting event in September 2002, special issue on the Antarctic stratospheric sudden warming and split ozone hole of 2002, J. Atmos. Sci., 62, 812-821, 2005.

Farman, J. C., Gardiner, B. G., and Shanklin, J. D.: Large losses of total ozone in Antarctica reveal seasonal $\mathrm{ClO}_{\mathrm{x}} / \mathrm{NO}_{\mathrm{x}}$ interaction, Nature, 315, 207, doi:10.1038/315207a0, 1985.

Fioletov, V. E., Bodeker, G. E., Miller, A. J., McPeters, R. D., and Stolarski, R. S.: Global and zonal total ozone variations estimated from ground-based and satellite measurements: 19642000, J. Geophys. Res., 107, 4647, doi:10.1029/2001JD001350, 2002.

Fioletov, V. E., Labow, G., Evans, R., Hare, E. W., Köhler, U., McElroy, C. T., Miyagawa, K., Redondas, A., Savastiouk, V., Shalamyansky, A. M., Staehelin, J., Vanicek, K., and Weber, M.: Performance of the ground-based total ozone network 
assessed using satellite data, J. Geophys. Res., 113, D14313, doi:10.1029/2008JD009809, 2008.

Harris, N. R. P., Kyrö, E., Staehelin, J., Brunner, D., Andersen, S.-B., Godin-Beekmann, S., Dhomse, S., Hadjinicolaou, P., Hansen, G., Isaksen, I., Jrrar, A., Karpetchko, A., Kivi, R., Knudsen, B., Krizan, P., Lastovicka, J., Maeder, J., Orsolini, Y., Pyle, J. A., Rex, M., Vanicek, K., Weber, M., Wohltmann, I., Zanis, P., and Zerefos, C.: Ozone trends at northern mid- and high latitudes - a European perspective, Ann. Geophys., 26, 12071220, doi:10.5194/angeo-26-1207-2008, 2008.

Huijnen, V., Williams, J., van Weele, M., van Noije, T., Krol, M., Dentener, F., Segers, A., Houweling, S., Peters, W., de Laat, J., Boersma, F., Bergamaschi, P., van Velthoven, P., Le Sager, P., Eskes, H., Alkemade, F., Scheele, R., Nédélec, P., and Pätz, H.-W.: The global chemistry transport model TM5: description and evaluation of the tropospheric chemistry version 3.0, Geosci. Model Dev., 3, 445-473, doi:10.5194/gmd-3-445-2010, 2010.

Inness, A., Baier, F., Benedetti, A., Bouarar, I., Chabrillat, S., Clark, H., Clerbaux, C., Coheur, P., Engelen, R. J., Errera, Q., Flemming, J., George, M., Granier, C., Hadji-Lazaro, J., Huijnen, V., Hurtmans, D., Jones, L., Kaiser, J. W., Kapsomenakis, J., Lefever, K., Leitão, J., Razinger, M., Richter, A., Schultz, M. G., Simmons, A. J., Suttie, M., Stein, O., Thépaut, J.-N., Thouret, V., Vrekoussis, M., Zerefos, C., and the MACC team: The MACC reanalysis: an 8 yr data set of atmospheric composition, Atmos. Chem. Phys., 13, 4073-4109, doi:10.5194/acp-13-4073-2013, 2013.

IPCC: Climate Change 2013: The Physical Science Basis, Contribution of Working Group I to the Fifth Assessment Report of the Intergovernmental Panel on Climate Change, edited by: Stocker, T. F., Qin, D., Plattner, G.-K., Tignor, M., Allen, S. K., Boschung, J., Nauels, A., Xia, Y., Bex, V., and Midgley, P. M., Cambridge University Press, Cambridge, UK, New York, NY, USA, 1535 pp., doi:10.1017/CBO9781107415324, 2013.

Kerr, J. B.: New methodology for deriving total ozone and other atmospheric variables from Brewer spectrophotometer direct sun spectra, J. Geophys. Res., 107, 4731, doi:10.1029/2001JD001227, 2002.

Knibbe, J. S., van der A, R. J., and de Laat, A. T. J.: Spatial regression analysis on 32 years of total column ozone data, Atmos. Chem. Phys., 14, 8461-8482, doi:10.5194/acp-14-84612014, 2014.

Krol, M., Houweling, S., Bregman, B., van den Broek, M., Segers, A., van Velthoven, P., Peters, W., Dentener, F., and Bergamaschi, P.: The two-way nested global chemistry-transport zoom model TM5: algorithm and applications, Atmos. Chem. Phys., 5, 417-432, doi:10.5194/acp-5-417-2005, 2005.

Krueger, A. J., Guenther, B., Fleig, A. J., Heath, D. F., Hilsenrath, E., McPeters, R., and Prabhakara, C.: Satellite ozone measurements, Philos. T. R. Soc. A, 296, 191-204, 1980.

Krzyścin, J. W.: Statistical reconstruction of daily total ozone over Europe 1950 to 2004, J. Geophys. Res., 113, D07112, doi:10.1029/2007JD008881, 2008.

Kuttippurath, J., Lefèvre, F., Pommereau, J.-P., Roscoe, H. K., Goutail, F., Pazmiño, A., and Shanklin, J. D.: Antarctic ozone loss in 1979-2010: first sign of ozone recovery, Atmos. Chem. Phys., 13, 1625-1635, doi:10.5194/acp-13-1625-2013, 2013.

Levelt, P. F., van den Oord, G. H. J., Dobber, M. R., Mälkki, A., Visser, H., de Vries, J., Stammes, P., Lundell, J., and Saari, H.:
The Ozone Monitoring Instrument, IEEE Trans. Geo. Remote. Sens., 44, 1093-1101, doi:10.1109/TGRS.2006.872333, 2006.

Lindfors, A., Tanskanen, A., Arola, A., van der A, R., Bais, A., Feister, U., Janouch, M., Josefsson, W., Koskela, T., Lakkala, K., den Outer, P. N., Smedley, A. R. D., Slaper, H., and Webb, A. R.: The PROMOTE UV Record: toward a global satellite-based climatology of surface ultraviolet irradiance, IEEE J. Sel. Top. Appl., 2, 207-212, doi:10.1109/JSTARS.2009.2030876, 2009.

Mäder, J. A., Staehelin, J., Brunner, D., Stahel, W. A., Wohltmann, I., and Peter, T.: Statistical modeling of total ozone: selection of appropriate explanatory variables, J. Geophys. Res., 112, D11108, doi:10.1029/2006JD007694, 2007.

Miller, A. J., Nagatani, R. M., Flynn, L. E., Kondragunta, S., Beach, E., Stolarski, R., McPeters, R. D., Bhartia, P. K., DeLand, M. T., Jackman, C. H., Wuebbles, D. J., Patten, K. O., and Cebula, R. P.: A cohesive total ozone data set from the SBUV(/2) satellite system, J. Geophys. Res., 107, 4701, doi:10.1029/2001JD000853, 2002.

Reinsel, C. G., Miller, A. J., Weatherhead, E. C., Flynn, L. E., Nagatani, R. M., Tiao, G. C., and Wuebbles, D. J.: Trend analysis of total ozone data for turn-around and dynamical contributions, J. Geophys. Res., 110, D16306, doi:10.1029/2004JD004662, 2005.

Staehelin, J., Harris, N. R. P., Appenzeller, C., and Eberhard, J.: Ozone trends: a review, Rev. Geophys., 39, 231-290, 2001.

Stolarski, R. S., Bloomfield, P., McPeters, R. D., and Herman, J. R.: Total Ozone trends deduced from Nimbus 7 Toms data, Geophys. Res. Lett., 18, 1015-1018, 1991.

Stolarski, R. S., Labow, G. J., and McPeters, R. D.: Springtime Antarctic total ozone measurements in the early 1970s from the BUV instrument on Nimbus 4, Geophys. Res. Lett., 24, 591-594, 1997.

Stolarski, R. S., Douglass, A. R., Steenrod, S., and Pawson, S.: Trends in stratospheric ozone: lessons learned from a 3-D chemical transport model, J. Atmos. Sci., 63, 1028-1041, 2006.

Uppala, S. M., Kållberg, P. W., Simmons, A. J., Andrae, U., Bechtold, V. D. C., Fiorino, M., Gibson, J. K., Haseler, J., Hernandez, A., Kelly, G. A., Li, X., Onogi, K., Saarinen, S., Sokka, N., Allan, R. P., Andersson, E., Arpe, K., Balmaseda, M. A., Beljaars, A. C. M., Berg, L. V. D., Bidlot, J., Bormann, N., Caires, S., Chevallier, F., Dethof, A., Dragosavac, M., Fisher, M., Fuentes, M., Hagemann, S., Hólm, E., Hoskins, B. J., Isaksen, L., Janssen, P. A. E. M., Jenne, R., Mcnally, A. P., Mahfouf, J.F., Morcrette, J.-J., Rayner, N. A., Saunders, R. W., Simon, P., Sterl, A., Trenberth, K. E., Untch, A., Vasiljevic, D., Viterbo, P., and Woollen, J.: The ERA-40 re-analysis, Q. J. Roy. Meteor. Soc., 131, 2961-3012, doi:10.1256/qj.04.176, 2005.

van $\operatorname{der}$ A, R. J., Allaart, M. A. F., and Eskes, H. J.: Multi sensor reanalysis of total ozone, Atmos. Chem. Phys., 10, 11277-11294, doi:10.5194/acp-10-11277-2010, 2010.

van Noije, T. P. C., Le Sager, P., Segers, A. J., van Velthoven, P. F. J., Krol, M. C., Hazeleger, W., Williams, A. G., and Chambers, S. D.: Simulation of tropospheric chemistry and aerosols with the climate model EC-Earth, Geosci. Model Dev., 7, 2435 2475, doi:10.5194/gmd-7-2435-2014, 2014.

Weber, M., Steinbrecht, W., van der A, R. J., Coldewey-Egbers, M., Fioletov, V. E., Frith, S. M., Long, C. S., Loyola, D., and Wild, J. D.: Global climate, stratospheric ozone, B. Am. Meteorol. Soc., 95, S38-S40, 2014. 
World Meteorological Organisation (WMO): Scientific Assessment of Ozone Depletion, 2006: Global Ozone Research and Monitoring Project - Report No. 50, Geneva, Switzerland, 572 pp., 2007.

World Meteorological Organization (WMO): Scientific Assessment of Ozone Depletion, 2014: World Meteorological Organization, Global Ozone Research and Monitoring Project - Report No. 55, Geneva, Switzerland, 416 pp., 2014.
WOUDC: These data were obtained from the World Ozone and U1traviolet Radiation Data Centre (WOUDC) operated by Environment Canada, Toronto, Ontario, Canada under the auspices of the World Meteorological Organization (1970-2012), available at: http://www.woudc.org/, last access: 4 February 2013. 